\title{
3
}

\section{The omnipresent past: Rethinking transitional justice through digital storytelling on Indonesia's 1965 violence}

\author{
Ken Setiawan
}

\begin{abstract}
Almost 20 years since the fall of authoritarianism, Indonesia is yet to deliver justice on the human rights violations the country witnessed during the New Order (1966-1998). As such, the Indonesian transitional justice process can be described at best as 'delayed' (Suh 2016, 241) or at worst as 'failed' (Kimura 2015,73). This raises the question of how Indonesian civil society actors have responded to this situation, particularly regarding arguably the most complex of past human rights violations in the country: the 1965-1966 violence (henceforth the 1965 violence) during which more than half a million were killed and hundreds of thousands were detained for long periods of time without trial. This chapter focuses on the recent emergence of digital activism on Indonesia's 1965 violence in which the non-witness generation, who were not physically present at the event (Jilovski 2015, 11), has taken a prominent role. I will discuss why these platforms have emerged and what the stories disseminated through them can tell about processes of transitional justice, taking a particular interest in the societal legacies of the violence.
\end{abstract}

This chapter starts with a historical background of the 1965 violence and the trajectory of transitional justice in Indonesia following the fall of the New Order regime in 1998 . The 1965 violence is particularly significant in the context of transitional justice in Indonesia, both because of its 
large scale and because it marked the ascendancy of authoritarian rule. Moreover, the New Order regime successfully hijacked the memory of the violence, portraying communists as traitors and a threat to stability and security. In so doing, the regime justified the killings as necessary for the nation's survival and legitimised its political rule. As this chapter will show, this discourse has remained strong in the post-authoritarian period despite increased human rights protections in law and the development of transitional justice mechanisms. The salience of this discourse has once again become evident during the current presidency of Joko Widodo ('Jokowi'), where dominant political discourses remain largely unconducive towards transitional justice efforts.

The second part of this chapter addresses how civil society actors continue to challenge these narratives, representing a 'fragile, but persistent culture of contestation' (Kuddus 2017, 82). Focusing on the emergence of digital storytelling websites on the 1965 violence, in which I also have been personally involved, I discuss why civil society actors have turned to digital media. Through analysing two stories of grandchildren of those who were directly affected by the 1965 events, I will argue that these websites are not only relevant for transitional justice because they seek to connect young people with a largely unknown past, but also because stories of the nonwitness generation convey how a dark chapter of history is experienced today. Using the concept of postmemory, or the strong connection of persons to an event that preceded their births (Hirsch 2008, 106-107), this chapter explores what the experiences of the non-witness generation may offer to the understanding of the transitional justice process in Indonesia, and in particular the societal legacies of state terror.

\section{The 1965 violence}

On the night of 30 September 1965, a group of conspirators in the Indonesian Army abducted and murdered six high-ranking generals and a lieutenant. Almost immediately Major General Suharto, the then commander of the Army Strategic Reserve, took action and crushed the '30th of September Movement' within a day. In the period that followed, the Army-controlled press labelled the movement as 'counter-revolutionary' and accused the PKI (Partai Komunis Indonesia; Indonesian Communist Party) of being its mastermind. In mid-October, Suharto was appointed commander of the Army, in which capacity he ordered troops to initiate operations against remnants of the movement. Between October 1965 and 
early 1966, approximately 500,000 party members and their sympathisers were killed, while another 600,000-750,000 were imprisoned, often for lengthy periods without trial (McGregor 2013, 138).

The massacres and mass imprisonments provided the stage for Suharto's ascendancy to power. He ruled the country until 1998, during which time Indonesia witnessed severe and systematic human rights violations. The Suharto regime, named the New Order, portrayed its role in crushing the 30 th of September Movement as saving the country from the communist threat. In so doing, it legitimised the killings and mass detentions, which served to eliminate the Indonesian Left and created an authoritarian state friendly to western geopolitical objectives in the context of the Cold War. ${ }^{1}$

With anti-communism being the cornerstone of the new regime, the consequences were grim for members of leftist organisations or individuals who had an affiliation to them. This included family members, who became 'Indonesia's own version of the untouchables' (McGregor 2013, 139). The stigmatisation of 'communists', a label used not only to describe party members but also anyone regarded as subversive, was propagated by the government through mass media and at schools. Consequently, during the New Order public memories of the 1965 violence were surrounded by 'fearful silence and ... collective amnesia' (Wahyuningroem 2013, 120). There was virtually no space for alternative discourses as political opposition was shut down violently by the Suharto regime. It was only after the fall of the New Order in 1998 that experiences of the violence could be shared in the public domain, and that human rights groups were able to demand openly that the government take responsibility for its crimes.

\section{Seeking to end an inconvenient past: Transitional justice in Indonesia}

In the immediate years following the fall of the New Order, human rights protections swiftly became incorporated into Indonesia's legal system because of international and domestic pressure. This included the enactment of the Human Rights Law (Law 39/1999), which provided

1 The elimination of the Left repositioned Indonesia into the Western bloc, and secured Western economic and military interests across maritime South-East Asia (McGregor 2013, 140-141). 
guarantees of both civil and political, as well as economic, social and cultural, rights and strengthened the legal status and mandate of Komnas HAM (Komisi Nasional Hak Asasi Manusia; the National Human Rights Commission). Human rights norms were also included in the Constitution (2000), which saw the addition of a specific chapter on human rights, modelled on the Universal Declaration of Human Rights (UDHR). In addition, the Human Rights Courts Law (Law 26/2000) established permanent Human Rights Courts with the jurisdiction over gross human rights violations including crimes against humanity and the crime of genocide. This law also provided the possibility to establish Ad Hoc Courts for cases that occurred before 2000. Indonesia ratified all major international human rights treaties, established a number of state institutions charged with human rights protection and introduced the first five-year National Action Plan on Human Rights (RANHAM), setting out priorities and strategies with regard to human rights implementation. State capacity for responding to present and past human rights cases thus improved remarkably (Setiawan 2016a, 12-13).

Yet justice for past human rights violations remained an uphill battle, whether through judicial or non-judicial mechanisms. To date, only two Ad Hoc human rights courts have been established. These concerned gross human rights violations in East Timor in the lead up to, and following, the 1999 independence referendum ${ }^{2}$ and the 1984 Tanjung Priok case. ${ }^{3}$ These tribunals did not have the desired outcomes: in both cases, only lower-ranked military officers were tried, and all were acquitted at various stages of the judicial process (Sulistiyanto 2007; Cammack 2016). While Komnas HAM recommended that a number of cases of past violations be addressed in Ad Hoc Courts, these were rejected by the Attorney General's Office (Setiawan 2016a, 24-25) and contributed to ongoing impunity. In 2012, following a lengthy investigation, Komnas HAM recommended the establishment of an Ad Hoc Court for the 1965 violence, ${ }^{4}$ which

\footnotetext{
2 This meant that violence perpetrated by the Indonesian military during the occupation of East Timor was excluded. The establishment of an Ad Hoc Court served to pre-empt the creation of an international tribunal (Cammack 2016, 191).

3 In the Tanjung Priok case, the Indonesian military opened fire on demonstrators led by Amir Biki, an Islamic leader and regime critic. The demonstration took place in the context of new policies to restrict the place of Islam in Indonesian politics. According to some estimates, 400 people were killed by the military.

4 In the same report, Komnas HAM also recommended the 1965 violence to be resolved through non-judicial means.
} 
was rejected by the Attorney General who argued that it was 'difficult to investigate cases which have happened that many years ago' (Voice of America 2012).

While the argument put forward by the Attorney General reflects a preference for non-judicial mechanisms, which has received renewed attention under the current presidency of Joko Widodo (see below), their establishment at the national level has been largely unsuccessful. ${ }^{5}$ In 2004, parliament passed Law 27/2004 on the Truth and Reconciliation Commission (TRC) to settle cases of past human rights violations outside of the courts. Drafted to address cases that occurred before the enactment of the 2000 Human Rights Courts Law, it was anticipated that the TRC would also address the 1965 violence. However, a number of provisions in the Law were problematic, including that compensation for victims would only be offered in conjunction with an amnesty. Several human rights organisations then brought the Law to the Constitutional Court, which agreed that this provision contradicted the Constitution and the principles of international law. However, rather than annulling the particular article, the Constitutional Court cancelled the entire law, leaving Indonesia without a formal non-judicial mechanism to settle past human rights violations.

The ineffectiveness of transitional justice mechanisms in Indonesia has been attributed to both a lack of political will to address past human rights violations (Sulistiyanto 2007, 90; Wahyuningroem 2013, 126) and to a direct result of the continued presence of New Order players in today's political elite (Kimura 2015, 88). Elite continuity has been identified as a major constraining factor in transitional justice efforts (Posner and Vermeule 2004, 770-772). In Indonesia, the domination of 'old faces' in Indonesian politics has been attributed to the characteristics of authoritarianism. Hadiz and Robison (2013) have ascribed this to the destructive nature of the previous regime that 'disorganised civil society and destroyed liberal forces' (Hadiz and Robison 2013, 36). The lack of political and ideological alternatives has thus allowed New Order elites to continue to yield power and wealth, while new players continue to engage with the political practices of the past. Aspinall has argued that during the New Order, political and social forces were tolerated as long as they obeyed the rule of the regime and did not challenge it directly. This led to

5 It should be noted that, at a local level, there have been some successful reconciliation processes. See, for instance, Wahyuningroem 2013 and Kuddus 2017. 
'semi-opposition', a combination of opposition and compromise, which has continued to influence the nature of the democratic transition and that explains why most key political forces after 1998 were either direct participants or marginal semi-oppositional players in the Suharto regime (Aspinall 2010, 21).

Both concepts draw relationships between present-day elite continuity and the nature of past authoritarianism. This has arguably limited the development of more liberal society and politics (Hadiz and Robinson 2013, 36) and led to low-quality democracy (Aspinall 2010, 32). In relation to human rights protections, this low-quality democracy is represented by significant institutional and legal reform on one hand, yet a lack of implementation on the other (Hadiprayitno 2010, 374; Setiawan 2016a, 5).

\section{Diluting transitional justice: The Jokowi presidency}

The 2014 election of Joko Widodo ('Jokowi') as president brought new hopes that past human rights violations would be addressed. This was influenced by the general, but inaccurate, perception ${ }^{6}$ that Jokowi had limited links to the military, political and business elites, which, as discussed above, are considered a key obstacle in human rights reform. Moreover, Jokowi was the only presidential candidate who explicitly promised to deliver justice for past human rights violations in his campaign program (Hearman 2014). Nawa Cita, the nine-point priority agenda put forward by Jokowi and his running mate Jusuf Kalla, stated that 'the just finalisation of past human rights violations' was of utmost importance, as they represented a 'social and political burden' on the country. This document also identified numerous past human rights violations that were to be addressed by the government, including the 1965 violence. $^{7}$ Once installed as president, Jokowi repeated the importance of solving

6 While Jokowi has far less direct ties to the New Order regime than his rival in the presidential contest, Prabowo Subianto, many of his allies are members of Indonesia's political and business elites, including some with a poor human rights record (see Warburton 2016, 304-305, 314).

7 In addition to the 1965 violence, the campaign program identified the following cases: Talangsari; Tanjung Priok; the enforced disappearances of activists in 1997-1998; the May 1998 violence; and the Trisakti and Semanggi shootings. 
past human rights cases in his 2015 State of the Nation address, stating that 'future generations may not be burdened by the past' (Sekretariat Kabinet Republik Indonesia 2015).

Many human rights activists supported Jokowi's campaign because of the promises made ${ }^{8}$ and expected his administration to bring past human rights violations to court. Instead, several non-judicial mechanisms were introduced, starting with the establishment of a Reconciliation Committee in May 2015 to address past human rights violations, including the 1965 mass violence (Setiawan 2016b). However, this initiative was abandoned after the August 2015 appointment of retired general Luhut Panjaitan to the post of Coordinating Minister of Politics, Law and Security. While in April 2016 Panjaitan supported the organisation of a National Symposium on the 1965 violence, ${ }^{9}$ opening dialogue between government officials, former members of the military and survivors, the recommendations of the symposium have not been released. Prospects for human rights reform became even more uncertain after the July 2016 appointment of retired general Wiranto as Coordinating Minister, replacing Panjaitan. Wiranto had been indicted by the United Nations in 2003 for atrocities committed in Timor-Leste. In early 2017, Wiranto announced the establishment of a National Harmony Council that would also be mandated to settle past human rights abuses (The Jakarta Post 2017).

The turn towards non-judicial mechanisms with little public participation and that shield those responsible for violations from being held to account can be explained by the ties that many members of the political elite have to organisations directly involved in human rights abuses. For example, Vice President Jusuf Kalla strongly denied rumours of a possible presidential apology ahead of the 50th anniversary of the 1965 violence. In the 1960s, Kalla had led the Indonesian Students Action Front in Makassar (South Sulawesi), which supported Suharto's rise to power. The strength of organisational ties was also evident among actors who were less directly involved than Kalla. Defence Minister Ryamizard Ryacudu, for instance, also rejected a possible apology. This position can be explained considering

8 At the same time, the support from many human rights activists for Jokowi can be understood as an effort to counter the rise of Prabowo Subianto, who was involved in human rights violations in East Timor and Papua, the enforced disappearances of democracy activists (1997-1998) and the 1998 violence.

9 It is likely that the symposium was organised in a response to heightened attention for the 1965 case domestically and abroad (McGregor and Purdey 2016). 
his previous role (2000-2002) as head of the Army Strategic Command, which four decades earlier played a crucial role in the annihilation of the Communist Party.

Ongoing elite influence must also be seen in the context of Jokowi's limited political authority, a result of his marginal win in the presidential elections (Setiawan 2016b). This has forced Jokowi to use a number of strategies in order to increase his power, including the building of alliances with conservative elites (Warburton 2016, 315). This has enabled Jokowi to expand his administration's programs that are primarily focused on the economy. These favour infrastructure, deregulation and de-bureaucratisation, with the reducing of red tape to enhance infrastructure projects being a personal priority of Jokowi (Warburton 2016, 308). At the political level there is thus little room for considering questions of justice for past human rights violations. Moreover, societal support for transitional justice is limited, with a broad section of the population showing reluctance or even antipathy (Kimura 2015, 89; Warburton 2016,315). Public discussions on the 1965 violence (including cultural events such book launches, photo exhibitions and film screenings) have been regularly shut down following pressure from the security forces or vigilante groups. ${ }^{10}$ While it is difficult to identify a pattern in these occurrences as many events proceed without any problems, pressure on civil society actors illustrates that the challenges for transitional justice for the 1965 violence are not only in the political and legal spheres, but also in the broader societal context.

\section{Beyond law and politics: Transitional justice as a societal process}

It is evident that in so far as Indonesia is willing to answer claims for justice for past human rights violations in general, and the 1965 case in particular, it favours the establishment of non-judicial mechanisms. These state-led initiatives have largely focused on reconciliation, without much attention given to establishing what has happened. It has been observed that political factions generally oppose the notion of 'truth', even when

10 Examples are the forced cancellation of a series of panels on 1965 at the Ubud Writers and Readers Festival (2015), the Belok Kiri (Turn Left) Festival (2016) and the 2017 attack on the Legal Aid Foundation, following its organisation of an academic discussion on the 1965 violence. 
they are more supportive of reform (Kimura 2015, 77-78). An example of that unease is that during the Jokowi presidency political discourses on historical justice have shifted from 'reconciliation' to 'harmony', with limited references to human rights frameworks or public participation. The primary concern of the Jokowi administration is to address these cases as quickly as possible: when the Reconciliation Committee was established, the government announced the committee would finalise its work within months. Both the administration's preference for the creation of shortterm institutions and its emphasis on 'closure' reflect an approach towards transitional justice characterised by short-term mechanisms, overlooking the social legacies of mass violence.

To an extent, the tendency towards a state-centric and top-down approach in transitional justice processes in Indonesia reflects many of these efforts globally, which, according to McEvoy (2007), have been dominated by legalism. One aspect of legalism is the institutionalisation of transitional justice, often leading to the establishment of 'state-like' structures including specialised courts and commissions. While the development of institutional capacity is important in the transition to more democratic forms of governance, this is no guarantee for success. As argued by McEvoy, one of the shortcomings of the institutionalisation of transitional justice is the tendency that these render justice as the business of the state. In this process, the complexities of past violence are oversimplified and fail to take into account local sources of knowledge. Similarly, these structures often do not engage sufficiently with the community and civil society, which means that they do not appropriately respond to the needs of its intended beneficiaries (McEvoy 2007, 421-424). In the Indonesian context, the top-down and state-centred approach is even more problematic because of the strong political and societal resistance towards transitional justice: it has more to do with protecting vested political interests, rather than delivering to those who have been affected by past violence.

One of the challenges of transitional justice mechanisms, whether of a judicial (i.e. special tribunals) or non-judicial (i.e. truth commissions) nature, is to acknowledge that the consequences of violence continue long after the event and even after the delivery of formal justice. In her seminal work on truth commissions, Priscilla Hayner remarked that, while these institutions are often welcomed as a way to break through social silences and an opportunity for healing, they 'do not offer longterm therapy' (Hayner 2001, 135). There is thus no direct correlation between transitional justice mechanisms and healing. As such, it is crucial 
to differentiate between justice processes pursued at a national and political level, and individual reconciliation (Hayner 2001, 157). This is more difficult to achieve, if it is at all possible: those who 'have suffered the long hand of power may never be able to stitch their lives together' (Gómez-Barris 2009, 26). Taking these realities into account, it is evident that transitional justice mechanisms will be more effective when they are part of a longer-term healing process. This constitutes a call to rethink transitional justice, taking it beyond traditional parameters of law and politics. Instead, transitional justice should be conceptualised as a process that concerns both the settling of accounts after violent conflict and the coming to terms with damages that have been inflicted on a society (Brants 2016, 16).

Coming to terms with the past requires the creation of a physical space where the past can exist in the present. From this perspective, transitional justice is thus intrinsically linked to storytelling. Indeed, 'the story' has increasingly gained prominence in human rights work (Kurusawa 2007). As testimonial acts, stories have various roles to play in the pursuit of justice. Not only do they generate factual knowledge about what has happened, to whom and who is responsible, but stories are also 'voices against silence, interpretation against incomprehension, empathy against indifference and remembrance against forgetting' (Kurasawa 2007, 25). As such, stories are invaluable in 'restitching the social fabric' (GómezBarris 2009, 94) in order for both individuals and society to come to terms with the past.

Cases of historical violence have shown us that the intense and often deeply painful experiences of the past are not only relevant for those who experienced it directly. Focusing on the remembrance of the Holocaust, Marianne Hirsch (2008) has argued that postmemory plays a crucial role in the intergenerational transmission of trauma. ${ }^{11}$ Postmemory is the relationship of individuals to experiences that preceded their births (Hirsch 2008, 103). It is thus not memory in a literal sense, but refers to a profound connection with the past that conveys the lasting presence of painful experiences. While postmemory is a generational structure of memory transmission taking place within the family, thus between first and subsequent generations, it also has a horizontal, or affiliative,

11 There are, of course, many differences between the Holocaust and the 1965 violence. In contrast to the Holocaust, there is not yet an authorised narrative on the 1965 violence that acknowledges the crimes, and to some extent survivors and their families continue to carry a stigma as a consequence of New Order propaganda. 
component. In an affiliative sense, postmemories serve to connect with a person's contemporaries who may not have a familial link (Hirsch 2008, 114-115). In reactivating a distant past and bringing it to the present, raising awareness of the event, postmemory is crucial to civil society transitional justice efforts. This is all the more relevant as time passes, and the distance between the present and the event increases, and there is arguably more knowledge to be generated.

Postmemory is not only relevant as a trigger for human rights activism, but also because it provides insights into the long-term and intergenerational effects of violence. This has been conceptualised by Macarena GómezBarris (2009) as the 'afterlife' of violence. In contrast to 'aftermath', defined as the political and economic legacies of past human rights violations, afterlife constitutes the struggles and realities of people living through political violence. Afterlife thus represents the continuing and persistent symbolic and material effects of the original event of violence on people's daily lives, their social and psychic identities, and their ongoing wrestling with the past in the present (Gómez-Barris 2009, 6).

In providing insights into what it means to live with the legacies of past violence, the concept of postmemory also allows us to critically consider transitional justice efforts, particularly when those have given little space for truth-telling.

\section{Digital storytelling on the 1965 violence}

While justice efforts for the 1965 violence continue to be disputed or rejected at the national political level, there is a growing awareness of and interest in these events, fed by various civil society activities and scholarly studies both in and outside of Indonesia (Kuddus 2017, 80-81). This includes the emergence of digital storytelling websites: 1965setiaphari ('1965 each day') ${ }^{12}$ and Ingat 65 ('Remember 65'). ${ }^{13}$ While there are differences between the two websites - Ingat 65, for instance, aims to develop 'a young people's movement ${ }^{14}$ whereas 1965 setiaphari is intended

12 The English-language component of the website is called Living1965. From 2018, 1965setiaphari has primarily used social media, including Instagram (@1965setiaphari) and Twitter (@1965setiaphari).

13 Other websites include Learning 65, initiated by the Culture-Centred Approaches to Research and Evaluation Centre at the National University of Singapore and the Yogyakarta-based Kotak Hitam Forum (Black Box Forum), which was established in 2008 and mainly produces short documentaries. 14 Ingat 65 Concept Note, on file with author. 
as an 'ongoing and living memorial' - there are also striking similarities. Both projects were initiated by individuals who have not experienced the events directly, or the non-witness generation. Similarly, many of the stories that appear on these websites have been contributed by young Indonesians reflecting on the 1965 violence, an event that they never directly experienced.

The use of digital platforms by civil society can be understood in the context of the global rise of digital technologies in general and in Indonesia in particular. With the fourth-highest number of Facebook users and Jakarta once named the most active city on Twitter, digital technologies in Indonesia are 'fast becoming the core of life, work, culture and identity' (Jurriëns and Tapsell 2017, 1). It is therefore unsurprising that civil society actors have turned towards these technologies. The popularity of social media is also important for the storytelling platforms as they largely rely on these avenues for the stories to be disseminated. In addition, the use of digital technology has numerous potential advantages, including that the projects are not situated in local contexts and are therefore not subject to some of the limitations of localised activism, such as the wider public's limited access to these efforts (Wahyuningroem 2013, 135). At the same time, it is important to recognise that most of Indonesia remains underdeveloped for digital technologies (Jurriëns and Tapsell 2017, 2) and thus not all Indonesians will be able to access the websites as intended by those who created them.

The emergence of the storytelling platforms on the 1965 violence should also be situated in a context where human rights issues remain highly contested. Discussing digital activism in the context of Papua, Postill and Saputro (2017) argue that digital technologies offer activists both a method to evade opposition from certain political and societal actors and a way to connect with like-minded people (Postill and Saputro 2017, 139). The digital storytelling platforms on the 1965 violence certainly avoid some of the challenges that many civil society actors have recently faced in the public sphere when attempting to debate the 1965 violence (Setiawan 2016c). Similarly, through the stories that are published on the websites, they raise awareness, particularly to an audience that generally lacks such knowledge about the 1965 violence and its afterlife. In so doing, the storytelling platforms create a new and alternative space, where voices and views excluded from mainstream discourses can exist, where they are not subject to censorship and physical intimidation, and where people can potentially connect across local and national boundaries. 


\section{Three generations removed: Grandchildren's stories}

In this section, I will discuss the stories of two grandchildren of the witness generation, Puri Lestari and Rangga Purbaya. Puri is the granddaughter of one of generals killed, while Rangga is the grandson of a member of a leftist organisation who was disappeared. Their stories illustrate their strong connection to an event that occurred before they were born, or postmemory, and the impact it has had on their families, thus providing insights into the afterlife of 1965.

Puri Lestari's story Ini kan buku komunis? (Isn't this a communist book?) appeared on Ingat65. The story gives an insight into the family of Mayor General Sutoyo, who was killed on the night of 30 September 1965. For Puri, 1965 is significant not only because of her grandfather's fate, but also because of her father, Agus Widjojo. A reformist general, Widjojo was an open supporter of reconciliation (Kuddus 2017, 71) and in 2016 was one of the key drivers of the National Symposium. Yet, during Puri's childhood 1965 was barely spoken about. Despite the silence in the family, Puri was curious - particularly as a photo framed in her grandmother's home also featured in a history textbook. But she did not ask any questions, especially after her mother warned her not to upset her father, described by Puri as 'one of thousands, if not millions, who experienced fear, pain, anger, disappointment, sadness and trauma'. However, as a university student in Australia Puri read what her father called 'communist books' (the work of the late author and former political prisoner Pramoedya Ananta Toer) and learned about Indonesias human rights record. Studying abroad proved to be a turning point for Puri, with the 2008 Apology to Australia's Stolen Generation ${ }^{15}$ offering an example how states can face their dark pasts and ask forgiveness. Accompanying her piece with a photo of her father and her child, Puri concludes that it represents 'his [Widjojo's] motivation to make peace, move on, and attempt to address the 1965 tragedy for Indonesia's new generation' (Lestari 2016).

An absent grandfather is also at the heart of Rangga Purbaya's story Di Mana Kakek? (Where Is Grandpa?). Featured on 1965setiaphari, Rangga’s story concerns his grandfather Boentardjo Amaroen Kartowinoto,

15 The Stolen Generation are Indigenous children who, between 1910 and 1970, were forcibly removed from their families as a result of various Australian Government policies. 
who was disappeared and presumably killed in 1965. In his essay, Rangga recalls his childhood visits to Yogyakarta and to his grandmother's grave, a common practice for Javanese families. However, he never visited his grandfather's grave, who, according to his father, was buried in Semarang. When Rangga was around eight years old, he looked at a family photo album with his father, finding a rather large picture of his grandfather. His father then told Rangga: 'If you see this person, talk to him immediately. Tell him you are his grandson, the son of Bima!' Surprised, Rangga asked his father 'but hasn't grandpa passed away?' The question was not answered and Rangga did not pursue it, but he realised later why his father was silent: '[he] was always hoping to find grandpa alive' (Purbaya 2016).

Both stories provide a glimpse into the intimate spaces of the family where the past continues to dwell. A striking resemblance between the two stories is that photographs of absent grandfathers triggered questions for both Puri and Rangga, illustrating that photographic images play a key role as a medium of postmemory (cf. Hirsch 2008, 115). The stories also illustrate the familial dimension of postmemory, as illustrated by the writers' conversations with their parents. At the same time, it is also through photographs that both essays bring the past into the present day. Puri Lestari uses a photo of her father and her child to position herself, as well as her father, in the political debate on the 1965 case. While Rangga's story does not have such an explicit message, his grandfather's disappearance has played a key role in his work as photographer, in which images of family members, personal objects (i.e. his grandfather's razor) and places (including sites of mass murder) prominently feature. As such, their stories and photographs also represent the affiliative aspect of postmemory, where past events transcend the space of the family and are shared in a larger context with contemporaries.

Through photos of their grandfathers, both Puri's and Rangga's stories evoke a sense of loss and the unknown. Puri's story, in particular, mirrors the experience of many young Indonesians who learned not to question official history and who only encountered alternative narratives following the fall of the New Order, or when studying abroad. Similarly, silence is also present in the story of Rangga, who during the New Order was unsure what had happened to his grandfather. However, as soon as Suharto stepped down, his father informed him about his grandfather's political affiliation. ${ }^{16}$ Their stories also raise the question of who was affected and

16 Personal communication. 
in what ways, as illustrated by Rangga's father's hope to find his father, and by Puri's comment that her father - the son of one of the 'Heroes of the Revolution' - was one of many who suffered, while not part of the leftist movement. Both stories thus give insights into the complex legacies of mass violence that continue to touch lives, including of those who were born many years later and never knew their grandparents.

\section{Conclusion}

While Indonesian governments since the end of authoritarianism have made tentative steps to address the violence of 1965 , these efforts have largely consisted of the enactment of laws and establishment of shortterm institutions. This legalistic but non-judicial approach has largely failed to address the societal legacies of the 1965 violence, which as this chapter has argued is a crucial aspect for both individuals and society to come to terms with the past.

The challenges of human rights reform in Indonesia, and particularly in the area of transitional justice, can largely be explained by the trajectory of democratisation that has been characterised by compromise and that has shielded those involved in human rights violations from being held accountable. In the area of human rights this has meant that while legal frameworks were established, their implementation leaves much to be desired. This can be attributed to the persistence of New Order elites that remain indifferent or even hostile towards transitional justice as a consequence of their political affiliations. The 1965 violence has been particularly complex in this context because the memory of the event was hijacked by the regime for its own political objectives. The argument that violence was justified in the interests of the nation, and by extension that thus there are no human rights issues to address, continues to command authority.

In this context, civil society actors have persistently challenged state narratives. They have made important contributions towards communicating the experiences of those who lived through the events of 1965 in an effort to raise awareness and enhance societal support for the justice process. In considering the recent emergence of digital storytelling platforms on the 1965 violence, this chapter has argued that they have both emerged as a response to the increased presence of digital technologies in Indonesians' lives, and the limited public space to discuss these events. 
As such, through using digital technologies alternative public spaces have been created, where knowledge on the 1965 violence and its ramifications is generated and can be debated freely. What distinguishes the digital platforms discussed in this chapter from other civil society efforts is that they have given a specific space to the non-witness generation, descendants of those who were directly affected by the violence, to share their experiences and thoughts.

The stories discussed in this chapter illustrate the strong connection individuals have with an event that preceded their births. These postmemories thus resurrect a distant past, bringing it to the present. Their stories evoke a sense of lives that were lost, families torn apart, silences and unanswered questions. In so doing, the stories not only seek to engage audiences with events that happened more than 50 years ago, but also enhance understanding of the deep scars that violence has inflicted on a society. As works of postmemory, the digital storytelling platforms are calling for a reconsideration of transitional justice beyond the paradigms of law and politics. Rather, a young generation is arguing that justice must be rooted in historical and social awareness, where the past can openly exist in the present.

\section{Bibliography}

Aspinall, Edward. 2010. 'The Irony of Success'. Journal of Democracy 21 (2): 20-34. doi.org/10.1353/jod.0.0157.

Brants, Chrisje. 2016. 'Introduction'. In Transitional Justice: Images and Memories, edited by Chrisje Brants, Antoine Hol and Dina Siegel, 1-12. London and New York: Routledge.

Cammack, Mark. 2016. 'Crimes against Humanity in East Timor. The Indonesian Ad Hoc Human Rights Court Hearings'. In Trials for International Crimes in Asia, edited by Kirsten Sellars, 191-225. Cambridge: Cambridge University Press. doi.org/10.1017/CBO9781316221754.010.

Gómez-Barris, Macarena. 2009. Where Memory Dwells. Oakland: University of California Press.

Hadiprayitno, Irene. 2010. 'Defensive Enforcement: Human Rights in Indonesia'. Human Rights Review 11:373-399. doi.org/10.1007/s12142-009-0143-1. 
Hadiz, Vedi and Richard Robison. 2013. 'The Political Economy of Oligarchy and the Reorganisation of Power in Indonesia'. Indonesia 96: 35-57. doi.org/ 10.1353/ind.2013.0023.

Hayner, Priscilla. 2001. Unspeakable Truths: Confronting State Terror and Atrocity. Routledge: New York and London. doi.org/10.4324/9780203903452.

Hearman, Vannessa. 2014. 'Spectre of Anti-Communist Smears Resurrected against Jokowi'. The Conversation, 4 July 2014.

Hirsch, Marianne. 2008. 'The Generation of Postmemory'. Poetics Today 29 (1): 103-128. doi.org/10.1215/03335372-2007-019.

The Jakarta Post. 2017. 'Wiranto Backtracks on Harmony Council's Purpose'. 10 March 2017.

Jilovsky, Esther. 2015. Remembering the Holocaust: Generations, Witnessing and Place. New York: Bloomsbury Academic. doi.org/10.5040/9781474210942.

Jurriëns, Edwin and Ross Tapsell. 2017. 'Challenges and Opportunities of the Digital 'Revolution' in Indonesia'. In Digital Indonesia: Connectivity and Divergence, edited by Edwin Jurriëns and Ross Tapsell, 1-18. Singapore: ISEAS - Yusof Ishak Institute. doi.org/10.1355/9789814786003-007.

Kimura, Ehito. 2015. 'The Struggle for Justice and Reconciliation in Post-Suharto Indonesia'. Southeast Asian Studies 4 (1): 73-93.

Kuddus, Rohana. 2017. 'The Ghosts of 1965. Politics and Memory in Indonesia'. New Left Review 104: 45-92.

Kurasawa, Fuyuki. 2007. The Work of Global Justice: Human Rights as Practices. Cambridge: Cambridge University Press. doi.org/10.1017/CBO9780511 619465.

Lestari, Puri. 2016. “'Ini kan buku komunis?” Kisah cucu pahlawan revolusi ["Isn't This a Communist Book?" The Story of a Grandchild of a Hero of the Revolution]'. Medium, 20 April. Available at medium.com/ingat-65/ini-kanbuku-komunis-d39a72da473f\#.vb1iyis0n (accessed 4 October 2017).

McEvoy, Kieran. 2007. 'Towards a Thicker Understanding of Transitional Justice'. Journal of Law and Society 34 (4): 411-440. doi.org/10.1111/j.14676478.2007.00399.x.

McGregor, Katharine E. 2013. 'Mass Violence in the Indonesian Transition from Sukarno to Suharto'. Global Dialogue 15 (1): 133-144. 
McGregor, Katharine E. and Jemma Purdey. 2016. 'Indonesia Takes a Small but Critical Step toward Reconciliation'. Indonesia at Melbourne (blog), 26 April. Available at indonesiaatmelbourne.unimelb.edu.au/indonesia-takesa-small-but-critical-step-toward-reconciliation/ (accessed 13 November 2019).

Posner, Eric A. and Adrian Vermeule. 2004. 'Transitional Justice as Ordinary Justice'. Harvard Law Review 117 (3): 761-825. doi.org/10.2307/4093461.

Postill, John and Kurniawan Saputro. 2017. 'Digital Activism in Contemporary Indonesia: Victims, Volunteers and Voices'. In Digital Indonesia: Connectivity and Divergence, edited by Edwin Jurriëns and Ross Tapsell, 127-145. Singapore: ISEAS - Yusof Ishak Institute. doi.org/10.1355/9789814786003-014.

Purbaya, Rangga. 2016. 'Di Mana Kakek? [Where is Grandpa?]'. \#1965setiaphari, 1 May. Available at 1965setiaphari.org/1965setiaphari/di-mana-kakek (accessed 4 October 2017).

Sekretariat Kabinet Republik Indonesia. 2015. 'Pidato Kenegaraan Presiden Republik Indonesia Dalam Rangka HUT Ke-70 Proklamasi Kemerdekaan Republik Indonesia Di Depan Sidang Bersama DPR RI dan DPD RI, Jakarta 14 Agustus 2015 [State Speech of the President of the Republic of Indonesia on the Occasion of the 70th Anniversary of the Proclamation of the Independence of the Republic of Indonesia at the Joint Session of the DPR RI and the DPD RI, Jakarta 14 August 2015]', Transcript. Available at setkab. go.id/pidato-kenegaraan-presiden-republik-indonesia-dalam-rangka-hut-ke70-proklamasi-kemerdekaan-republik-indonesia-di-depan-sidang-bersamadpr-ri-dan-dpd-ri-jakarta-14-agustus-2015/ (accessed 18 May 2017).

Setiawan, Ken. 2016a. 'From Hope to Disillusion. The Paradox of Komnas HAM, the Indonesian National Human Rights Commission'. Bijdragen tot de Taal-, Land-en Volkenkunde 172: 1-32. doi.org/10.1163/22134379-17201002.

Setiawan, Ken. 2016b. 'The Politics of Compromise'. Inside Indonesia 123 (January-March). www.insideindonesia.org/the-politics-of-compromise-2.

Setiawan, Ken. 2016c. 'The Fear of Communism Still Haunts Indonesia'. Indonesia at Melbourne (blog), 3 March. Available at indonesiaatmelbourne. unimelb.edu.au/belok-kiri-fest-fear-of-communism-still-haunts-indonesia/ (accessed 13 November 2019).

Suh, Jiwon. 2016. 'The Suharto Case'. Asian Journal of Social Science 44: 214-245. doi.org/10.1163/15685314-04401009.

Sulistiyanto, Priyambudi. 2007. 'Politics of Justice and Reconciliation in PostSuharto Indonesia'. Journal of Contemporary Asia 37 (1): 73-94. doi.org/ $10.1080 / 00472330601104623$. 
Voice of America. 2012. 'Korban Peristiwa 1965-66 Kecewa dengan Kejakasaan Agung [Victims of the 1965-66 Event Disappointed with Attorney General]', 12 November.

Wahyuningroem, Sri Lestari. 2013. 'Seducing for Truth and Justice: Civil Society Initiatives for the 1965 Mass Violence in Indonesia'. Journal of Current Southeast Asian Affairs 32 (3): 115-142. doi.org/10.1177/186810341303200306.

Warburton, Eve. 2016. 'Jokowi and the New Developmentalism'. Bulletin of Indonesian Economic Studies 52 (3): 297-320. doi.org/10.1080/00074918. 2016.1249262 . 
This text is taken from Civil Society and Transitional Justice in Asia and the Pacific, edited by Lia Kent, Joanne Wallis and Claire Cronin, published 2019 by ANU Press, The Australian National University,

Canberra, Australia.

doi.org/10.22459/CSTJAP.2019.03 